\title{
Exercise and consumption of herbal remedies decrease the risk of strokes in hypertension and diabetes mellitus patients undergoing a standard therapy
}

\author{
Akrom $^{* 1,2}$, Melisa Rizki ${ }^{1}$ \\ ${ }^{1}$ Faculty of Pharmacy, Universitas Ahmad Dahlan, Yogyakarta \\ ${ }^{2}$ Center for Drug Information and Studies, Universitas Ahmad Dahlan,Yogyakarta
}

Submitted: 17-05-2019

Reviewed: 20-05-2019

Accepted: 14-08-2019

\begin{abstract}
Stroke is a serious problem faced worldwide. It can result in death, physical disability, and mental disability. Hypertension and Diabetes Mellitus (DM) patients are high-risk populations. The study attempted to determine the factors associated with the incidence of stroke in DM or hypertension outpatients. This analytic observational study used a case-control design and nonrandom sampling technique with consecutive sampling approach. With a 1:2 ratio, the subjects consisted of 49 stroke patients in the case group and 98 non-stroke patients (hypertensive) for the control group. Subjects were patients undergoing treatments at PKU Muhammadiyah Hospital in Bantul. Patient's lifestyle data were collected through face-to-face interviews with patients, while demographic information, diagnosis, and patient history were obtained from medical records using data retrieval forms (case record forms). The variable age was matched with sex to improve the efficiency and accuracy of the study. Data analysis included univariate (descriptive) analysis and bivariate analysis using the ChiSquare test. Factors associated with stroke incidence were smoking habit $(\mathrm{OR}=2.940, \mathrm{CI}: 1.314<\mathrm{OR}$ <6.576; $\mathrm{P}=0.007)$, exercise routine $(\mathrm{OR}=0.026$, CI: $0.008<\mathrm{OR}<0.079, \mathrm{P}=0.000)$, high-fat food dietary pattern $(\mathrm{OR}=3.629$, CI: $1.119<\mathrm{OR}<11.766 ; \mathrm{P}=0.024)$, and the habit of consuming herbal remedies $(\mathrm{OR}=0.299$, CI: $0.107<\mathrm{OR}<0.833 ; \mathrm{P}=0.016)$. For hypertension or $\mathrm{DM}$ patients who took standard therapy at PKU Muhammadiyah Hospital in Bantul, smoking and fatty food consumption increased the risk of stroke, whereas physical exercise and herbs consumption habits reduced it.
\end{abstract}

Keywords: stroke risk factors, physical exercises; herbal medicine; smoke; diabetes mellitus

\section{*Corresponding author:}

Akrom

Faculty of Pharmacy, Ahmad Dahlan Drug Information and Crisis Center

Universitas Ahmad Dahlan, Yogyakarta

Email: akrom@pharm.uad.ac.id 


\section{INTRODUCTION}

Nowadays, strokes have increasingly posed a severe problem worldwide (Junaidi, 2011). Riskesdas (2013) claims that the prevalence of stroke in Indonesia is rising and Yogyakarta ranks the second largest city in Indonesia with $16.9 \%$ incidences. Patients with hypertension and diabetes mellitus (DM) are high-risk groups (Burhanuddin et al., 2012; Dinata et al., 2013). Previous research has proven that the incidence of stroke is higher in hypertension or DM patients (AHA, 2010; Sofyan et al., 2012). The risk of strokes also increases when patients live an unhealthy lifestyle (Bhatt, Malik, and Chaturvedi, 2018; Kim et al., 2019).

In the case of DM and hypertension, the ways of living or lifestyles of the patients are thought to be closely related to stroke (Kim et al., 2019; Rambe, 2006). An example includes smoking habits that increase the risk of heart diseases and strokes compared to non-smokers (Burhanuddin et al., 2012). Nicotine in cigarettes causes vasoconstriction that can lead to elevated blood pressure. Smoking can also reduce HDL levels in the blood. All effects of nicotine can accelerate the process of atherosclerosis and blockage of blood vessels, creating preconditions of strokes (Lloyd-Jones et al., 2010). An increased risk of stokes is also attributable to frequent fatty foods consumption (O'Donnell et al., 2016). According to Junaidi (2006), fatty foods affect cholesterol levels in the body.

High cholesterols result in atherosclerosis, that is, the accumulation of cholesterol in and on the walls of blood vessels that narrows blood vessels and disrupts the blood supply to the brain (stroke) (Janssen et al., 2011: Lee et al., 2017). In people with hypertension, physical activity or exercise can decrease the incidence of stroke (Lennon et al., 2018). It is a form of repetitive stimulation to the body, which can make the lumen of blood vessels widen and more elastic. During exercise, blood can pass through blood vessels smoothly without forcing the heart to generate higher pressure to pump out the blood. Consequently, a wide lumen can prevent atherosclerosis and strokes (Baldwin et al., 2010; Silva et al., 2014; Smith et al., 2006). Furthermore, regular consumption of herbal remedies or medicinal plants is known to prevent strokes because it can repair (strengthen) tissues and blood vessels in the brain, which reduce the probability of rupture (Jain et al., 2018). Antioxidants in herbs can counteract free radicals that cause strokes (Dröge, 2002; Nabyl, 2012; Rastogi et al., 2017). No studies have correlated regular consumption of herbal remedies with the incidence of strokes. This research is intended to identify this correlation and is, therefore, different from previous studies on the risk factors of strokes and can contribute to the search for effective stroke prevention methods. Also, it aimed to determine the relationship between smoking habits, regular exercise, and consumption of fatty foods and the incidence of strokes in DM patients with hypertension at PKU Muhammadiyah Hospital, Bantul.

\section{MATERIALS AND METHOD \\ MATERIALS}

\section{Research Type and Design}

This analytic observational study employed a case-control approach where the researcher first determined the disease (outcome, i.e., stroke) then identified the cause (exposure, i.e., lifestyle as a risk factor). This design included case groups (stroke patients) and control groups (non-stroke patients) and matched or equalized the age and sex of patients in both groups. Then, it identified the research subjects retrospectively to find out the relationship between patients' habits, namely smoking, physical exercise, fatty food intake, and consumption of herbal remedies, and the incidence of stroke in DM patients with hypertension at PKU Muhammadiyah Hospital, Bantul. The research design is depicted in Figure 1. 


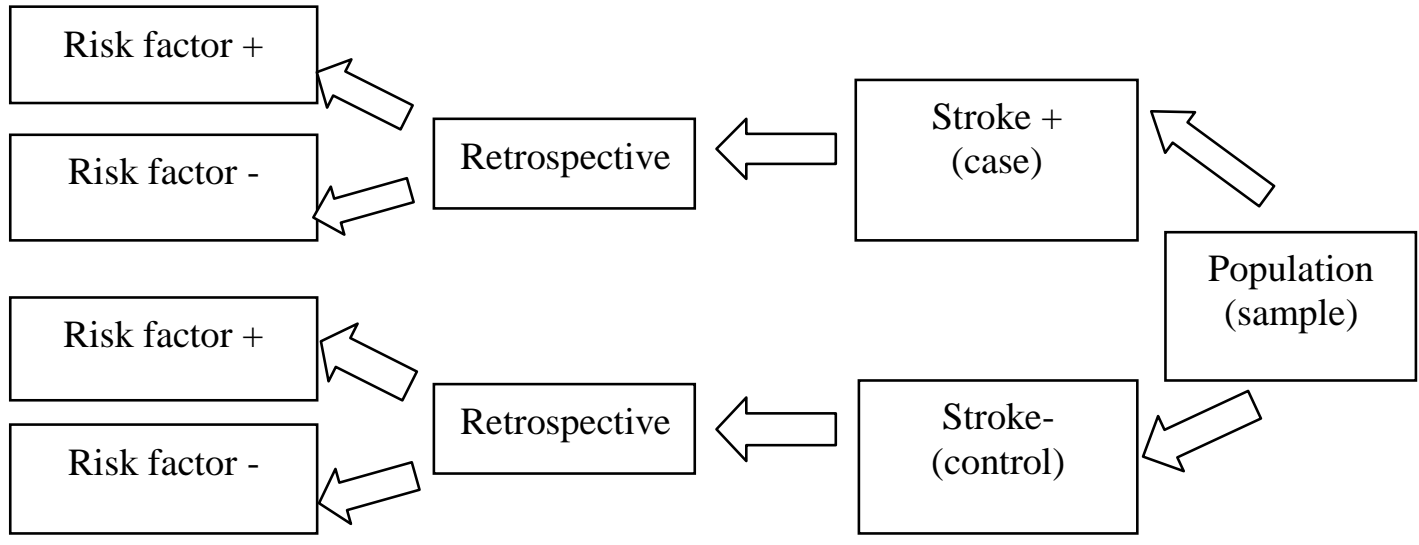

Figure 1. The Type and Design of the Research. The correlation between smoking habits, exercise routine, high-fat dietary pattern, and consumption of herbal remedies and the incidence of stroke in DM patients with hypertension at PKU Muhammadiyah Hospital, Bantul (Sastroasmoro, 2002)

\section{Population and sample}

The research population was all stroke patients registered at PKU Muhammadiyah Hospital, Bantul, from December 2014 until April 2015 (Tomi et al., 2016), while another population for comparison consisted of all non-stroke patients at the same hospital in March 2017.

\section{Research sample}

The samples were stroke patients (data collected from December 2016 to April 2017) and nonstroke patients (in March 2017) at PKU Muhammadiyah Hospital in Bantul who were willing to participate in the research. The sampling was carried out with inclusion and exclusion criteria. The case group included patients at the age of 40-90 years old who were willing to be the research subject, were diagnosed with either ischemic or hemorrhagic stroke by the doctors at this hospital and hospitalized in December 2016-April 2017, and did not experience disturbances of consciousness during the data acquisition. The control group consisted of patients at the age of 40-90 years old who were willing to be involved in the study, suffered from hypertension or diabetes mellitus but not diagnosed with strokes, underwent outpatient treatment in March 2017, and experienced no disturbances of consciousness during the data collection. The exclusion criteria for both groups were patients who died during hospital care, left against medical advice, or resigned.

\section{Sampling technique}

The research employed non-probability sampling with consecutive selection technique. Consecutive here means that all subjects who come and meet the selection criteria will be included in the study until the required number of samples is reached (Sastroasmoro, 2002).

\section{Estimated sample size}

The study used the formula for two population proportions to determine the sample size (Lemeshow et al., 1997), as seen below. The computation involved this assumption: a significance level of $95 \%$ with $z \alpha=1.96$ and the desired power of $90 \%$ with $z \beta=1.28$. 


$$
\begin{aligned}
n & =\frac{\{Z \alpha \sqrt{2 P Q}+Z \beta \sqrt{P 1 Q 1+P 2 Q 2}\}^{2}}{(P 1-P 2)^{2}} \\
& =47.4
\end{aligned}
$$

Notes: $\mathrm{n}=$ Minimum sample size, $\mathrm{P} 1=$ The proportion of the case group (stroke patients) $=57.9 \%=0.579$ (Riskesdas, 2013); Q1= 100\% - P1 $(57.9 \%)=42.1 \%=0.421$;

$\mathrm{P} 2=$ The proportion of the control group (hypertension patients $)=25.8 \%=0.258($ Riskesdas, 2013); $\mathrm{Q} 2=100 \%$ - $\mathrm{P} 2(25.8 \%)=74.2 \%=0.742 ; \mathrm{P}=(\mathrm{P} 1+\mathrm{P} 2) / 2=0.4185$;

$\mathrm{Q}=(\mathrm{Q} 1+\mathrm{Q} 2) / 2=0.582 ; \mathrm{Z} \alpha=1.96(95 \%$ significance level; $\mathrm{Z} \beta=1.28$ (the desired power of the test $=90 \%)$

The results showed that a minimum sample of 47.4 patients would be required. This study used a 1:2 ratio for the sample size, namely 49 patients in the case group and 98 patients in the control group.

\section{TOOLS AND MATERIALS}

The research used both primary and secondary data. The secondary data were obtained from the patient's medical record, and the primary data were from questionnaire-guided interviews. Tools like questionnaires and data collection forms (Case Record Form) were used to acquire these data.

\section{Research variables and their operational definition}

The independent variable was lifestyles, as a risk factor, whereas the dependent variable was the incidence of stroke. The external variables consisted of controlled variables, namely age and sex, and uncontrolled ones, namely genetic factors. The lifestyle here referred to smoking, physical exercise, high-fat food dietary, and consumption of herbal remedies that patients performed as habits or routine. During direct interviews, patients provided this information based on the items asked in the questionnaires or data collection forms.

Age is the number of years the patients have lived, which was calculated from the date of birth. In this study, it was analyzed in nominal dichotomous scale that divided it into two groups, namely $1=$ Geriatric $(\geq 60$ years) and $2=$ Non-geriatric $(<60$ years). The sampled patients were between 40 and 90 years old, as obtained by moving the information from their medical records into the questionnaires/data collection forms. The medical records also contained information about the sex of the patients (i.e., male or female), which was then transferred into the questionnaires/data collection forms. The measurement scale of the sex data was nominal dichotomous, namely $1=$ Male and $2=$ Female.

Education represents the formal education attainment stated by the respondents during questionnaire-guided direct interviews or as written on the medical records. The measurement of this data used ordinal scale, namely $0=$ No school, $1=$ Elementary School, $2=$ Middle School, $3=$ High School, 4 = Diploma I or DI (equivalent to Associate Degree with one-year course), $5=$ Diploma III or DIII (equivalent to Associate Degree with three-year course), and $6=$ Bachelor's Degree. Employment is an activity that links one human to others as an effort to meet needs and has certain goals, namely earnings or income. This variable was identified from any details regarding the type of work or daily source of income that the patients conveyed during direct interviews (questionnaires/data collection forms). The measurement used an ordinal scale, namely $0=$ Unemployed, $1=$ Civil Servant, $2=$ Entrepreneur, 3 = Farmer, Private Sector Worker, Labor, and 4 = Fisher.

The four variables of lifestyle, namely the habits of smoking, exercise, high-fat food dietary, and consumptions of and herbal remedies, were all measured through face-to-face interviews with the respondents, and their responses were then written in the questionnaires or data collection forms. First, smoking habits define how frequent someone smokes, whether daily or occasionally (sometimes). In this study, this variable was measured with a nominal dichotomous scale, namely $1=$ Smokers and $2=$ Non-smokers. The respondents were categorized as smokers if they had been smoking at least one 
cigarette per day for the past five years (i.e., active smokers) or had stopped smoking for $\leq 5$ years. Meanwhile, non-smokers were those who had never smoked cigarettes at all or stopped smoking for > 5 years. Second, physical exercise habits show the routine of sports activities performed by patients before receiving treatments at PKU Muhammadiyah Hospital, Bantul. This variable was assessed using a nominal dichotomous scale, namely $1=$ Exercise and $2=$ No exercise. Habits were when patients had one or more physical activity at least once a week, such as morning walks or jogs, cycling, gymnastics, badminton, volleyball, and silat martial arts. The respondents fell into the category 'No exercise' when they practiced sports less than once a week to never. Third, fatty foods are fast foods, foods processed from chicken, beef, and lamb, and foods prepared with coconut milk. The measurement scale of this variable was nominal dichotomous, namely $1=$ Frequently and $2=$ Not. The first group was respondents who frequented fatty foods at least three times a week. On the contrary, patients who ate them less than three times a week to never belonged to the second group. Fourth, herbal remedies include factory- and homemade concoctions, standardized herbal medicine, and phytopharmaceuticals. The habit of taking herbal remedies was measured with a nominal dichotomous scale, namely $1=$ Frequently and $2=$ Not. Patients were classified into having a habit of taking herbal remedies when they consumed them at least three times a week, while for those who drank them less than three times a week to never were included in the second group.

The case group consisted of stroke patients who were diagnosed with ischemic (nonhemorrhagic), hemorrhagic, or unidentified strokes and hospitalized at PKU Muhammadiyah Hospital in Bantul during the observation period, i.e., December 2016-April 2017. Data on prospective subjects were collected by transferring information from their medical records to questionnaires or data collection forms. The stroke details were designed into nominal polychotomous data; namely $1=$ Nonhemorrhagic stroke, 2= Hemorrhagic stroke, and 3= Unidentified stroke. As the control group, hypertensive patients were those who were diagnosed with either single hypertension or hypertension with complications or comorbidities other than stroke and underwent outpatient treatments at PKU Muhammadiyah Hospital, Bantul, in December 2016-March 2017. The information about the sampled patients in this group was moved from their medical records into the questionnaire or data collection form. The incidence of hypertension was measured as a nominal dichotomous data, namely $1=$ Single hypertension and $2=$ Hypertensive complications.

\section{METHODS}

\section{Preparation}

At this stage, the forms and data collection tools were prepared, and the ethical clearance and research permits at PKU Muhammadiyah Hospital in Bantul were arranged. Afterward, a preliminary test followed.

\section{Implementation and data collection procedure}

Having obtained an explanation of the benefits and objectives of the study, the prospective subjects who were willing to participate were asked to fill out a form of informed consent and a statement of agreement to be the respondents in the study.

The research employed retrospective approach, that is, by taking the data on stroke patients (case group) and non-stroke patients diagnosed with hypertension (control group) that were later used as the samples for the study at PKU Muhammadiyah Hospital in Bantul. The implementation phase was carried out with the following order. (i) The details (i.e., names, date of birth, age, sex, address, medical record number, telephone number, diagnosis, and history of the disease) of patients diagnosed with ischemic and hemorrhagic strokes and non-stroke hypertensive patients who received treatments at PKU Muhammadiyah Hospital, Bantul, at the time of the study were collected. (ii) The patients who decided to participate filled out and signed an informed consent sheet. (iii) Interviews were conducted face-to-face with patients to fill out the prepared health assessment and lifestyle sheets, covering educational attainment, employment, smoking habits, 
exercise, and consumptions of fatty foods and herbal remedies. (iv) All information provided by the respondents was recorded and analyzed to see its relationship with the incidence of stroke.

Data Analysis

The data were processed statistically in SPSS v.16, and the characteristics of the subject were presented descriptively. Bivariate analysis was also performed using the chi-square test to assess the correlation between lifestyle (smoking habits, exercise routine, high-fat food dietary, and consumption of herbal remedies) and stroke in patients with DM and hypertension (Luepker et al., 2004).

\section{RESULTS AND DISCUSSION}

The characteristics of the research subjects

The distribution of the characteristics of the research subjects at PKU Muhammadiyah Hospital in Bantul is listed in Table I.

Table I. The characteristics of the research subjects at PKU Muhammadiyah Hospital-Bantul in December 2014-April 2015 for the case group (stroke patients) and March 2017 for the control group (hypertensive patients)

\begin{tabular}{|c|c|c|c|c|}
\hline CHARACTERISTICS & CASE & CONTROL & TOTAL & $\mathbf{P}$ \\
\hline Age $(>60$ or $\leq 60$ years old $)$ & $31 / 18$ & $61 / 37$ & $92 / 55$ & 0.94 \\
\hline Sex (male/female) & $20 / 29$ & $40 / 58$ & $60 / 87$ & 0.99 \\
\hline Education (basic/tertiary) & $41 / 9$ & $53 / 44$ & $94 / 53$ & $0.00 *$ \\
\hline Employment (Civil servant-private sector worker/unemployed) & $7 / 42$ & $37 / 61$ & $44 / 103$ & $0.03 *$ \\
\hline Consumption of herbal remedies (frequently/not) & $5 / 44$ & $27 / 71$ & $32 / 115$ & $0.02 *$ \\
\hline Consumption of fatty foods (frequently/not) & $8 / 41$ & $5 / 93$ & $13 / 134$ & $0.01 *$ \\
\hline Exercise habits (yes/no) & $4 / 45$ & $76 / 22$ & $80 / 67$ & $0.00 *$ \\
\hline Smoking habits (yes/no) & $17 / 32$ & $15 / 83$ & $32 / 115$ & $0.01 *$ \\
\hline
\end{tabular}

Notes: ${ }^{*}=$ statistically significant $(\mathrm{p}<0.05)$

The case group consisted of 16 non-hemorrhagic stroke patients, six hemorrhagic stroke patients, and 27 unidentified stroke patients. Meanwhile, the control group had 46 single hypertensive patients and 52 hypertensive patients with complications. Table I shows that most of the subjects are female aged $>60$ years old who work as labors or are unemployed, have primary education, routinely exercise, consume no herbal remedies, and do not smoke. Women also make up for more than half of the case group (29 women, 59.2\%) and the control group (58 women, 59.2\%). Based on employment, strokes were mostly identified in patients who work as farmers, private sector workers, and labors, namely 26 people $(53.1 \%)$.

\section{Bivariate analysis of lifestyle factors and stroke}

The results of the bivariate analysis for the correlation between lifestyle factors, i.e., smoking habits, physical exercise routine, high-fat food dietary, and consumption of herbal remedies, and strokes in DM patients with hypertension at PKU Muhammadiyah Hospital in Bantul are presented in Table II. 
Table II. The relationship between lifestyle and stroke in hypertensive patients at PKU Muhammadiyah Hospital, Bantul, in December 2014-April 2015 for the case group (stroke patients) and in March 2017 for the control group (hypertensive patients with or without diabetes mellitus)

\begin{tabular}{lcccc}
\hline \multicolumn{1}{c}{ Lifestyle } & Case & Control & OR & P \\
\hline Smoking/not smoking & $17 / 32$ & $15 / 83$ & $2.94(\mathrm{CI} 95 \%: 1.31-6.57)$ & 0.007 \\
Exercise/not exercise & $4 / 45$ & $76 / 22$ & $0.026(\mathrm{CI} 95 \%: 0.008-0.08)$ & 0.000 \\
$\begin{array}{l}\text { High-fat food dietary } \\
(\geq 3 \mathrm{x} / \text { week)/not }\end{array}$ & $8 / 41$ & $5 / 93$ & $3.629(\mathrm{CI} 95 \%: 1.12-11.77)$ & 0.024 \\
$\begin{array}{l}\text { Consumption of herbal } \\
\text { remedies/not }\end{array}$ & $5 / 44$ & $27 / 71$ & $3.346(\mathrm{CI} 95 \%: 1.20-9.33)$ & 0.016 \\
\hline
\end{tabular}

\section{The correlation between exercise and stroke}

The results of the bivariate analysis for the relationship between exercise routine and stroke in hypertensive patients at PKU Muhammadiyah Hospital in Bantul are presented in Table II. Exercise habits were found to associate with a decrease in stroke incidence with an Odds Ratio (OR) of 0.026 and $p$-value of $0.000(\mathrm{p}<0.00)$, indicating that exercise can prevent stroke. The sampled patients mentioned that their physical exercise routine included morning walks and jogs, cycling, badminton, gymnastics, soccer, volleyball, and silat martial art at least three times a week for 20-30 minutes.

People who are less physically active have an almost $50 \%$ higher risk of stroke compared to those who are active (Sutrisno, 2007). In a prospective study (Junaidi, 2006), 7,735 British men aged 40-59 years have shown the benefits of moderate physical activity in significantly reducing the risk of stroke. Regular physical activity lowers blood pressure, blood sugar levels, and LDL levels, increases HDL cholesterol levels, loses weight, and encourages smoking cessation. It builds not only the capacity of the cardiovascular system but also the ability to deal with physical and psychological stress (Junaidi, 2011). The reason is it can widen the lumen of the blood vessels and change glucose and food reserves into energy to normalize blood sugar levels and decrease HbA1c (Naqvi et al., 2017). Also, it allows blood to flow through blood vessels smoothly without having to put more pressure on the heart and, therefore, the buildup of reactive radical compounds that trigger inflammatory reactions in the body can be prevented. Another benefit is that atherosclerosis becomes more difficult to form in those who have a wider blood vessel lumen (Kim et al., 2018). On the contrary, lack of physical activity can stiffen muscle and blood vessels and induce obesity in which fat deposits in the blood clog the circulation of the blood (Dourman, 2013). The results of this study are in line with Dahrizal (2009), which states that physical activity has a statistically significant correlation with strokes and that low physical activity increases the risk of stroke by 2.32 times.

\section{The correlation between smoking habit and stroke}

Table II shows that smoking habits are associated with a higher risk of stroke in patients with hypertension or DM that have been receiving standard therapy $(\mathrm{OR}=2.940 ; p$-value $=0.007<0.00)$. This result proves that smoking is one of the stroke triggers in hypertension or DM patients undergoing standard therapy, which confirms the findings in Jannah (2001). A study in Makassar City also concludes that smoking behavior increases the risk of strokes by 2.68 times in early adulthood (Burhanuddin et al., 2012). Smokers have a seven times greater risk of stroke than non-smokers (Lipska et al., 2007; Viveca et al., 2008). Smoking, the real cause of stroke, can transfer toxic substances in cigarettes into the lungs, which then narrows the arteries and elevates the possibility of strokes (Puspita and Putro, 2008). According to Junaidi (2006), such risk increases by 2-3 times in smokers, and the effect of smoking can last 5-10 years. Smoking can increase fat oxidation, and cigarettes contain various kinds of chemicals from tobacco, tar, pesticides, chemicals for combustion 
and polonium (radioactive) and have atherogenic, hematological, and rheological effects - potential factors of stroke.

Nicotine in cigarettes causes vasoconstriction, that is, the constriction of blood vessels that leads to elevated blood pressure. The arteries also experience constriction, and the walls of blood vessels become easily torn, resulting in high platelet production and easily clogged blood. Moreover, smoking can adversely affect blood fat and reduce HDL levels in the blood. All effects of nicotine from cigarettes can accelerate the process of atherosclerosis and blockage of blood vessels. Carbon monoxide from cigarettes can also reduce the amount of oxygen carried by the blood, causing an imbalance between the necessary amount of oxygen and the oxygen transported by the blood (Stroke Association, 2010).

Pharmacists need to provide hypertension and DM patients who receive routine therapy with education about the need to avoid exposure to cigarette smoke and to stop smoking. Policies and interventions on the prevention of tobacco use, promotion of smoke-free environments, and smoking cessation should be included in the national and international efforts to improve people's health and welfare. An example includes raising tobacco taxes, warning about the dangers of tobacco, and enforcing a ban on tobacco advertising (Lennon et al., 2018; Mendis et al., 2011).

\section{The correlation between fatty food consumption and stroke}

The research subjects were grouped into those who frequently ate greasy food ( $>3$ times per week) and those who did not. Patients in the case group (stroke patients) often consumed fast foods, foods derived from chicken, beef, and lamb, and foods cooked with coconut milk. Table II shows that frequent consumption of high-fat foods is associated with an increased risk of stroke in hypertension or DM patients who go through standard therapy $(\mathrm{OR}=3.629 ; p$-value $=0.024<0.05)$.

According to Junaidi (2006), the habit of consuming foods high in fat and cholesterol will affect cholesterol in the body. Lipids play a prominent role in the process of atherosclerosis (the buildup of plaque), and in this case, patients need to be wary of high LDL, low HDL, and high triglyceride levels. LDL oxidized by free radicals triggers the formation of atheroma in the arterial walls (atherosclerosis). High cholesterol allows the accumulation of cholesterol in the walls of blood vessels, causing narrowed vessels and disrupted blood supply to the brain (stroke). Foods containing lots of fat and cholesterol, when consumed in excess, will increase cholesterol levels in the blood. Total cholesterol, represented by LDL and HDL levels, and other fats in the blood must not exceed $200 \mathrm{mg} / \mathrm{dl}$. Cholesterol is a substance in the bloodstream that can accumulate in and on the walls of blood vessels when present in high concentration. This effect can lead to the narrowing of blood vessels, which then interferes with the blood supply to the brain (Junaidi, 2011). The results of this study are in line with Puspita and Putro (2008), which state that there is a relationship between consumption of fatty and high-cholesterol foods and the incidence of stroke at Regional General Hospital in Gambiran, Kediri. According to Kristiyawati et al. (2009), high LDL cholesterol is a precondition of stroke. If it is upwards of $150 \mathrm{mg} / \mathrm{dl}$, the risk of blood vessel constriction is likely to increase (Erphinz, 2008; Furie et al., 2011).

\section{The correlation between the consumption of herbal remedies and stroke}

Table II shows the bivariate analysis results between routine consumption of herbal remedies and the incidence of stroke in hypertensive patients at PKU Muhammadiyah Hospital, Bantul. The habit of drinking herbal remedies is associated with a reduced risk of stroke $(\mathrm{OR}=0.299 ; p$-value $=$ $0.016<0.5)$. Hypertensive patients who consume herbal medicine have a lower risk of stroke than the ones who do not, by nearly one-third (0.299 times).

Prolonged empirical experiences have proven the efficacy of herbal medicine. Previous research has shown that most herbs used by the public contain two essential components, namely immunomodulators and anti-oxidants (Rastogi et al., 2016). Antioxidants are substances that can counteract the harmful effects of free radicals generated as the results of oxidative metabolism, i.e., the 
chemical reactions and metabolic processes occurring in the body (Halliwell and Gutteridge, 2007; Jain et al., 2018; Naqvi et al., 2017). Antioxidants can stop or break the chain reactions of free radicals found in the body, preventing body cells from damages (Hernani and Rahardjo, 2005). These substances give one electron to free radicals and make them non-radical or neutralized (Cheng et al., 2017; Rohmatussolihat, 2009).

Free radicals are one of the causes of several diseases in the human body. Scientific evidence points to the ability of antioxidant compounds to lowering the risk of chronic conditions, such as cancer and coronary heart disease (Amrun et al., 2007). Accordingly, this research also observed the preventive effects of antioxidants contained in herbs on strokes to analyze their correlation. The results showed that five patients in the case group (10.2\% of the stroke patients) and 27 in the control group (27.6\% of the DM patients with hypertension) drank herbal remedies frequently. The chi-square test yielded $\mathrm{OR}=0.299,(0.107<\mathrm{OR}<0.833), p$-value $=0.016$, and Confidence Interval $(\mathrm{CI})=95 \%$, meaning that hypertensive DM patients who form a habit of consuming herbal remedies have a 0.299-time lower risk of suffering strokes compared with those who do not. Since the $p$-value is $0.016(<0.05)$, this correlation is considered as statistically significant and proves that drinking herbal remedies regularly can reduce the occurrence of stroke in hypertensive DM patients who undergo standard therapy. This finding is in line with previous studies that have identified the functions of medicinal plants in stroke treatment, including to prevent stroke, repair or strengthen cell tissues and blood vessels in the brain (prevent rupture), recover damaged brain cell tissues and nerve cells after a stroke attack, and re-normalize the dysfunctioned muscles after strokes (Cheng et al., 2017; Nabyl, 2012).

Based on the above findings, this research suggests that pharmacists have to provide education or information to hypertensive patients with or without DM who undergo therapy about the necessary change to a healthier lifestyle. DM patients with hypertension who go through drug therapy must also receive such education or information to avoid smoking, exercise regularly, reduce the consumption of high-fat foods, and consume herbal medicines. The role of pharmacists in the management of diabetes mellitus with hypertension has to be expanded so that they not only assist in the provision of drugs and administration but also deliver education for proper behavior during treatments, namely adopting a better lifestyle to achieve the targets of the therapy.

The case-control design employed in this research has one disadvantage; that is, the respondents' memory about the risk factors may create a bias. Therefore, a follow up using a cohort or clinical trial becomes necessary to ascertain the influence of exercise or herbal medicine on reduced stroke occurrences.

\section{CONCLUSION}

Regular exercise, high-fat foods dietary, consumption of herbal remedies, and no smoking habit decrease the incidence of stroke in hypertensive DM patients who undergo therapy with standard medicines at PKU Muhammadiyah Hospital, Bantul.

\section{ACKNOWLEDGMENT}

Authors would like to express their gratitude to all volunteers who participated as respondents in this research. Authors would also like to thank the Chief of PKU Muhammadiyah Hospital in Bantul, as well as the staff, for granting permissions and providing assistance during the research.

\section{REFERENCES}

AHA, 2010, Heart disease and stroke statistics - 2010 Update. Dallas, Texas: American Heart Association.

Amrun, H.M, Umiyah, and Evi Umayah U., 2007, Uji Aktifitas Antioksidan Ektrak Air dan Ektrak Metanol Beberapa Varian Buah Kenitu (Chrysophyllum cainito L) dari daerah Jember, Berk. Penel. Hayati.

Baldwin, K., Orr, S, Briand, M., Piazza, C., Veydt, A., and McCoy S., 2010, Acute ischemic stroke update from pharmacotherapy. J Medscape. 
Bhatt, Malik, and Chaturvedi., 2008, Dose-Response Relationship Between Cigarette Smoking And Risk Of Ischemic Stroke In Young Women, Stroke, 39(9): 2439-2443.

Burhanuddin, M., Wahiduddin., and Jumriani., 2012, Faktor Risiko Kejadian Stroke pada Dewasa Awal (18-40 tahun) di Kota Makassar tahun 2010-2012. Research Article. Makassar: Universitas Hassanudin.

Cheng, Y.-C. Sheen, J.M., Hu, W.L., Hung, Y.C., 2017, Polyphenols And Oxidative Stress In Atherosclerosis-Related Ischemic Heart Disease And Stroke, Oxidative Medicine and Cellular Longevity, 2017: 1-16.

Dahrizal, 2009, Pola makan dan hiperurisemia sebagai faktor risiko kejadian stroke pada pasien yang dirawat di rumah sakit Mayjen H.A. Thalib Kabupaten Kerinci. Research Report. Bagian Ilmu Kesehatan Masyarakat FK UGM, Yogyakarta.

Dinata, C.A., Safitra, Y., and Sastri, S., 2013, Gambaran faktor risiko dan tipe stroke pada pasien rawat inap di bagian penyakit dalam rsud kabupaten solok selatan periode 1 januari 2010 - 31 juni 2012. Jurnal Kesehatan Andalas, 2(2): 57-61.

Dourman, 2013, Waspadai Stroke Usia Muda. Jakarta: Cerdas Sehat.

Dröge, W., 2002, Free Radicals in the Physiological Control of Cell Function', Physiological Reviews, 82(1): 47-95.

Erphinz, 2008, Peningkatan Kolesterol LDL Sebagai Faktor Risiko Stroke. http://strokebethesda.com/component/option.com.

Furie, K. L., Kasner, S. E., Adams, R. J., Albers, G. W., Bush, R. L., Fagan, S. C., et al., 2011. Guidelines For The Prevention Of Stroke In Patients With Stroke Or Transient Ischemic Attack: A Guideline For Healthcare Professionals From The American Heart Association/American Stroke Association. Stroke, 42(1), 227-276.

Halliwell, B., and Gutteridge, J.M.C., 2007, Free radicals in biology and medicine. 4th eds. New York: Oxford.

Hernani and Rahardjo., 2005, Tanaman Berkhasiat Antioksidan. Jakarta: Penebar Swadaya.

Jain, S. Buttar HS, Chintameneni M, Kaur G., 2018, Prevention of Cardiovascular Diseases with AntiInflammatory and Anti- Oxidant Nutraceuticals and Herbal Products: An Overview of PreClinical and Clinical Studies, Recent Patents on Inflammation and Allergy Drug Discovery, 12(2): $145-157$.

Jannah, N. 2001, Faktor-faktor risiko terjadinya stroke perdarahan di ruang rawat inap RSUD Dr. Soetomo. Skripsi. Surabaya, Universitas Airlangga.

Janssen, A. W. M., de Leeuw, F. E. and Janssen, M. C. H., 2011, Risk Factors For Ischemic Stroke And Transient Ischemic Attack In Patients Under Age 50, Journal of thrombosis and thrombolysis. Springer, 31(1): 85-91.

Junaidi, I. 2006, Stroke A-Z. PT Bhuana Ilmu Populer, Jakarta.

Junaidi, I. 2011, Stroke Waspadai Ancamannya. Yogyakarta: ANDI.

Kim, J. Y. Kang K, Kang J, Koo J, Kim DH, Kim BJ, et al., 2019, Executive Summary of Stroke Statistics in Korea 2018: A Report from the Epidemiology Research Council of the Korean Stroke Society. Journal of stroke. Korean Stroke Society, 21(1): 42-59.

Kristiyawati, S.P., Irawaty, D., and Hariyati, Rr.T.S., 2009, Faktor Risiko yang Berhubungan de-ngan Kejadian Stroke di RS Panti Wilasa Citarum Sema-rang, Jurnal Keperawatan dan Kebidanan (JIKK). Semarang: STIKES Telogorejo, 1(1): 1-7.

Lee, J., Son, H. and Ryu, O. H., 2017, Management Status of Cardiovascular Disease Risk Factors for Dyslipidemia among Korean Adults., Yonsei medical journal. Yonsei University College of Medicine, 58(2): 326-338.

Lemeshow, S. 1997, Besar Sampel dalam Penelitian Kesehatan. Gadjah Mada University. Yogyakarta. Lennon, O. Blake, C., Lawrence, M., 2018, Interventions For Behaviour Change And SelfManagement In Stroke Secondary Prevention: Protocol For An Overview Of Reviews., Systematic Reviews. BioMed Central, 7(1): 231. 
Llyoid-Jones, D., Adams, RJ., Brown, T.M., Carnethon, M., Dai, S., De Simone, G.,Ferguson, T.B., Ford, E., Furie, K., Gillespie; C., Go, A., Greenlund, K., Haase, N., Hailpern, S., 2010. Executive Summary: Heart Disease and Stroke Statistics-2010 Update, Circulation, 121(7), February 23, 2010.

Luepker, R.V., Evans, A., Mckeigue, P., and Reddy K.S., 2004, Cardiovascular Survey Methods. Geneva: WHO.

Lipska, K. Sylaja, P.N., Sarma, P.S., Thankappan, K., Kutty, V.R., Vasan, R.S., Radhakrishnan, K., 2007, Risk Factors For Acute Ischaemic Stroke In Young Adults In South India., Journal of neurology, neurosurgery, and psychiatry. BMJ Publishing Group, 78(9): 959-63.

Mendis, S., Puska, P., and Norrving, B., 2011, Global Atlas On Cardiovascular Disease.World Health Organization, World Heart Federation, World Stroke Organization.

Nabyl, R. A., 2012, Panduan hidup sehat: Mencegah dan Mengobati Diabetes Melitus. Aulia publishing. Yogyakarta.

Naqvi, S. Naveed, S., Ali, Z., Ahmad, S.M., Asadullah, R., 2017, Correlation between Glycated Hemoglobin and Triglyceride Level in Type 2 Diabetes Mellitus, Cureus, 9(6): e1347.

O’Donnell, M. J., Chin, S. L., Rangarajan, S., Xavier, D., Liu, L., Zhang, H., Yusuf, S. 2016, Global and regional effects of potentially modifiable risk factors associated with acute stroke in 32 countries (INTERSTROKE): a case-control study. The Lancet, 388(10046): 761-775.

Puspita, M.R., and Putro, G. 2008, Hubungan Gaya Hidup terha-dap Kejadian Stroke di Rumah Sakit Umum daerah Gambiran Kediri, Buletin Penelitian Sistem Kesehatan.

Rambe, A., 2006, Stroke: Sekilas Tentang Definisi, Penyebab, Efek, dan Faktor Risiko. Medan: Majalah Kedokteran Nusantara, 10 (2): 195-198.

Rastogi, S., Pandey, M. M. and Rawat, A. K. S., 2016, Traditional Herbs: A Remedy Fo Cardiovascular Disorders, Phytomedicine, 23(11): 1082-1089.

Rastogi, S., Pandey, M. M. and Rawat, A. K. S., 2017, Spices: Therapeutic Potential in Cardiovascular Health, Current Pharmaceutical Design, 23(7): 989-998.

Riset Kesehatan Dasar (Riskesdas). 2013, Badan Penelitian dan Pengembangan Kesehatan Kementerian RI tahun 2013. Accessed: August 20, 2016, from http://www.depkes.go.id/resources/download/general/Hasil\%20Riskesdas\%20 2013.pdf.

Rohmatussolihat, 2009. Antioksidan, Penyelamat Sel-Sel Tubuh Manusia, BioTrends, 4(1):5-9.

Sastroasmoro, 2002, Dasar-Dasar Metodologi Penelitian Penelitian Klinis. Jakarta: CV. Sagung Seto.

Silva, D.A., Venketasubramanian, N., Roxas, A.A., Kee, L.P., and Lampl, Y., 2014, Understanding Stroke. A Guide For Stroke Survivor and Their Families. Moleac: www.neuroaid.com : 1-384.

Smith SC Jr, Allen J, Blair SN, Bonow RO, Brass LM, Fonarow GC, et al., 2006, AHA/ACC Guidelines for Secondary Prevention for Patients With Coronary and Other Atherosclerotic Vascular Disease: 2006 Update, Circulation. Lippincott Williams and Wilkins, 113(19): 23632372.

Sofyan, A.M., Sihombing, I.Y., and Hamra, Y., 2012, Hubungan Umur, Jenis Kelamin, dan Hipertensi dengan Kejadian Stroke. Program Pendidikan Dokter FK UHO.

Stroke Association, 2010, Converging Risk Factors. January 4, 2017. www.strokeassosiation.org.

Sutrisno, A. 2007, Stroke? You Must Know Before You Get It. Jakarta: Gramedia Pustaka Utama.

Tomi., Akrom., and Jatiningrum, A., 2016. Gambaran Medication Error Pada Fase Prescribing dan Administrasi Pada Pengobatan Stroke di IGD Rumah Sakit X di Yogyakarta. Thesis, Magister Farmasi Klinis Universitas Ahmad Dahlan.

Viveca M.Bhat., JohnW. Cole., John D. Sorkin., Marcella A. Wozniak., Ann M.Malacher., Wayne H, Giles., Barney J. Stern., Steven J., Kittner., 2008, Dose-Response Relationship Between Cigarette Smoking and Risk of Ischemic Stroke in Young Women. Journal of The American Stroke Association, 39(9):2439-2443. 
